\title{
Copper deficiency: Diagnosis and treatment in a long term jejunostomy fed patient who presented with peripheral neuropathy and myelodysplasia
}

\author{
F. Ross ${ }^{1}$, D. Turner ${ }^{1}$, P. Roberts ${ }^{1}$, M. Blundell ${ }^{1}$ and J. Rahamim ${ }^{2}$ \\ ${ }^{1}$ Torbay Hospital, Newton road, Torquay, Devon TQ2 7AA and ${ }^{2}$ Derriford Hospital, Crownhill, Plymouth PL6 8DH, UK
}

A 64 year old patient with an oesophagostomy on total jejunostomy feeding following oesophageal cancer surgery and anastomotic breakdown in 2006 was referred to Torbay haematology department with pancytopenia and a peripheral neuropathy in February 2011. B12 levels were low but the pancytopenia failed to respond to B12 injections. A bone marrow biopsy confirmed myelodysplastic syndrome (MDS) and the patient was started on a programme of blood transfusions. Further blood tests confirmed copper deficiency as a likely cause of his MDS.

\begin{tabular}{|c|c|c|c|c|c|c|c|}
\hline Date & $\begin{array}{c}\text { WBC* } \\
\text { Normal } \\
4-10 \\
10 * 9 / \mathrm{L}\end{array}$ & $\begin{array}{l}\text { Haemaglobin } \\
\text { Normal } \\
13-18 \mathrm{~g} / \mathrm{dL}\end{array}$ & $\begin{array}{c}\text { Platelets } \\
\text { Normal } \\
150-400 \\
10 * 9 / \mathrm{L}\end{array}$ & $\begin{array}{c}\text { Neutrophils } \\
\text { Normal } \\
1.8-7.5 \\
10^{*} 9 / \mathrm{L}\end{array}$ & $\begin{array}{c}\text { Copper } \\
\text { umol/1 } \\
\text { Normal } \\
(11-25.1)\end{array}$ & $\begin{array}{c}\text { Zinc } \\
\text { umol/l } \\
\text { Normal } \\
(11.4-24.8)\end{array}$ & Comments \\
\hline $09 / 2007$ & 1 & 1 & I & 1 & 19.0 & 7.1 & Patient started on Zinc \\
\hline $02 / 2011$ & 2.0 & 7.0 & 116 & 0.6 & $<1.0$ & 14.8 & $\mathrm{Cu}$ deficiency \\
\hline $05 / 2011$ & 6.9 & 11.6 & 129 & 2.5 & 13.9 & Not repeated & Completed treatment \\
\hline
\end{tabular}

*wbc $=$ white blood cell count.

The patient received $3 \mathrm{mg}$ intravenous copper infusions over 8 hours in $250 \mathrm{mls}$ normal saline on 3 days a week for 6 weeks on the haematology day unit. Soluble zinc supplementation via the patients jejunostomy was stopped due to possible interaction with copper absorption from the enteral feed. There were no symptoms of zinc toxicity. Following the 18 copper infusions, his serum copper level returned to normal and his pancytopenia resolved. The patient has reported some but not total improvement in peripheral neuropathy with copper supplementation. The patient has now been discharged from the haematology department and will have his full blood count, copper and zinc level monitored as part of a routine nutrition assessment within the home enteral feeding service.

This case highlights copper deficiency as a potential cause of MDS in patients who have a history of complex gastrointestinal surgery, jejunostomy feeding and zinc supplementation. Annual monitoring of copper and zinc levels in high risk enterally fed patient groups may help to detect early deficiency. Caution is required if zinc is used without clinical signs of deficiency in patients receiving jejunostomy feeding as this may interfere with copper absorption and could result in secondary myelodysplasia and peripheral neuropathy.

1. Fong T, Vij R, Vijayan A, Dipersio J \& Blinder M (2007) Copper deficiency: an important consideration in the differential diagnosis of myelodysplastic syndrome. Haematologica/The haematology journal 92 (10), 1429-1430.

2. Rowin J \& Lewis S (2005) Copper deficiency myeloneuropathy and pancytopenia secondary to overuse of zinc supplementation. Journal of neurology and neurosurgical 76, 750-751. 